\title{
Market Integration in the International Coal Industry: A Cointegration Approach
}

\author{
Linda Wårell*
}

The purpose of this paper is to test the hypothesis of the existence of a single economic market for the international coal industry, separated for coking and steam coal, and to investigate market integration over time. This has been conducted by applying cointegration and error-correction models on quarterly price series data in Europe and Japan over the time period 1980-2000. Both the coking and the steam coal markets show evidence of global market integration, as demonstrated by the stable long-run cointegrating relationship between the respective price series in different world regions. This supports the hypothesis of a globally integrated market. However, when analyzing market integration over time it is not possible to confirm cointegration in the 1990s for steam coal. Thus, compared to the coking coal market, the steam coal market looks somewhat less global in scope.

\section{INTRODUCTION}

The international coal industry has been characterized by fundamental changes during the last decades. In the 1960s the coal market could not be considered as international. Production was almost exclusively aimed at national usage, and trade between different world regions was infrequent. The oil crises in 1973 and 1979 forced a revision of this setting and demand for coal, especially traded coal, increased substantially. This development has been further encouraged

The Energy Journal, Vol. 27, No. 1. Copyright $\odot 2006$ by the IAEE. All rights reserved.

* Luleå University of Technology, Department of Business Administration and Social Science, Division of Economics, 97187 Luleå, Sweden, Fax: +46 9204920 35, E-mail: Linda.Warell@Itu.se.

A shorter version of this paper was presented at the International IAEE conference in Aberdeen, June 26-29, 2002. Generous financial support from the Swedish Competition Authority is gratefully acknowledged, as are helpful comments from Patrik Söderholm, Bo Jonsson, Marian Radetzki, Mats Nilsson, Anders Lunander, John Tilton, James Griffin, and three anonymous referees. Any remaining errors, however, remain solely with the author. 
by the significant decreases in shipping costs during this time period (Lundgren, 1996). Since 1970, world demand for coal has increased by more than 60 percent, which is even faster than the increase of world demand for oil. However, the most considerable increase was in traded coal, which increased by over 230 percent (Keay, 2003). In light of these trends many analysts have considered the international coal market as an essentially unified global market (e.g., Ellerman, 1995; Humphreys and Welham, 2000).

Lately, the coal industry has experienced a number of mergers and acquisitions, leading to a more concentrated market (Regibeau, 2000). The question whether these new and larger companies can exert market power has, as a consequence, been raised. In order to measure market power, and establish a market as anti-competitive, it is important to define the relevant market boundaries. Market definition is the first step taken by competition authorities when assessing whether a prospective merger is likely to lessen competition via either coordinated interaction or unilateral effects. However, market definition is only an initial step, and further investigations are necessary to establish the presence of anti-competitive behaviour. The results of these tests will, though, be strongly affected by the defined market boundary. For instance, mergers within a particular country or region will be less problematic if the relevant market is world-wide instead of local.

The purpose of this paper is to test the hypothesis of a world market for coal, and to investigate whether the industry has experienced increased market integration over time. International trade and price relationships in spatially separated markets are the main focus of the analysis. The general concept of the 'law of one price' is used for defining the presence of a single market. The logic behind this is that when there is trade between two regions, the price differential, in equilibrium, should not exceed the transport cost between them. For example, consider a large coal exporter, e.g., Australia, shipping to Japan and Europe. The equilibrium price-differential between Europe and Japan should be the difference in shipping costs between Australia-Europe and Australia-Japan.

Spatial equilibrium analysis has a long history dating back to Samuelson (1952). In the late 1980s and early 1990s many authors began to use time-series techniques to correlate prices in spatially separated markets (deVany and Walls, 1993; Sauer, 1994; Asche et al., 2001). Cointegration testing has become a common way of investigating the law of one price, and will be used here together with an analysis of short-run price adjustments. The present paper's contribution is to apply these techniques to two kinds of internationally traded coal: steam and coking coal.

The paper proceeds as follows. Section two examines the historical development of internationally traded steam and coking coal. Section three provides a theoretical background to cointegration and error-correction models. In section four the empirical results are presented, and the last part of this section divides the price-series data into different time periods in order to study market integration over time. Finally, in section five, some concluding remarks are made. 


\section{THE DEVELOPMENT OF THE INTERNATIONAL COAL INDUSTRY}

Before the 1960s the coal market was mainly national, and most trade was land-based between neighboring countries. A natural obstacle to the development of a world market for traded coal, compared with e.g., oil, has been the high transportation costs involved in shipping and handling coal (IEA, 1997). According to Lundgren (1996) freight-rates for bulk products, such as coal, have however decreased by about $65-70$ percent since the 1950 s. This created an opportunity for a global market for seaborne traded coal to emerge. Figure 1 illustrates the development of world trade of steam and coking coal, from 1978 to $2000 .^{1}$ Regarding coking coal we can see that world trade almost doubled during this time period. World trade in steam coal has grown considerably faster, an increase of more than 438 percent in traded steam coal during the last two decades. One reason for this can be ascribed to the high oil prices imposed by the OPEC cartel in the 1970s, which substantially increased the demand for coal as input into electricity generation. This market has continued to grow, something which is mainly explained by the high energy consumption levels in the world today. Due to the different uses and developments of coking and steam coal, these products will be treated separately in the remainder of the article. ${ }^{2}$

\section{Figure 1. World Trade for Steam and Coking Coal}

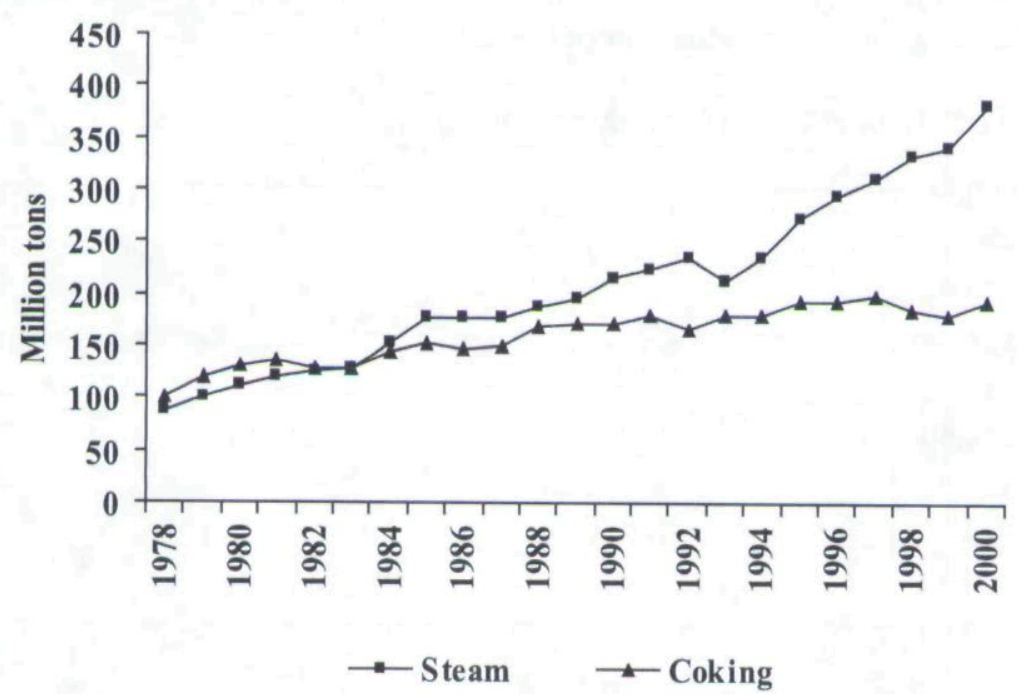

Source: IEA (2001). (IEA).

1. Data separating steam and coking coal date back to 1978 at the International Energy Agency

2. Substitution between coking coal and steam coal is possible but it requires considerable preparation of the products, in order to go with either the steel making process or the energy process (IEA, 1998). 


\subsection{Coking Coal}

Coking coal is primarily used as a chemical reductant in iron and steel production. Growth in the coking coal market was most evident during the 1960s. This can be explained by a booming steel-making industry in Europe, which did not have significant resources of coal. The higher demand for coking coal in the European market therefore led to significant trade of seaborne coal. During the 1970s the demand for coking coal increased substantially in the newly industrializing countries in Asia and Latin America. During the 1980s growth in the coking coal market slowed down due to the modest growth in industrial usage for coking coal (mainly in Europe), and a new technical process that decreased the need for coke in the steel making process (IEA, 1997).

In 2000, the total export volume in coking coal was 192 million tons and the largest exporter, Australia, represented more than 50 percent of the market. Figure 2 presents coking coal price levels for Europe and Japan from 1980 until 2000. It is evident from this figure that the prices in these geographically separated markets tend to be closely correlated. The prices for coking coal are generally settled in long-term contracts (more than five years) through bilateral negotiations between suppliers and consumers. During the last decade spot markets for coal have developed, but these are still limited in scope since the demand for coking coal is to a large extent fixed in the short-run. There is though evidence that the prices paid in spot markets have an effect on the contract price settlements, especially in the European market (IEA, 1997).

\section{Figure 2. Import Prices for Coking Coal}

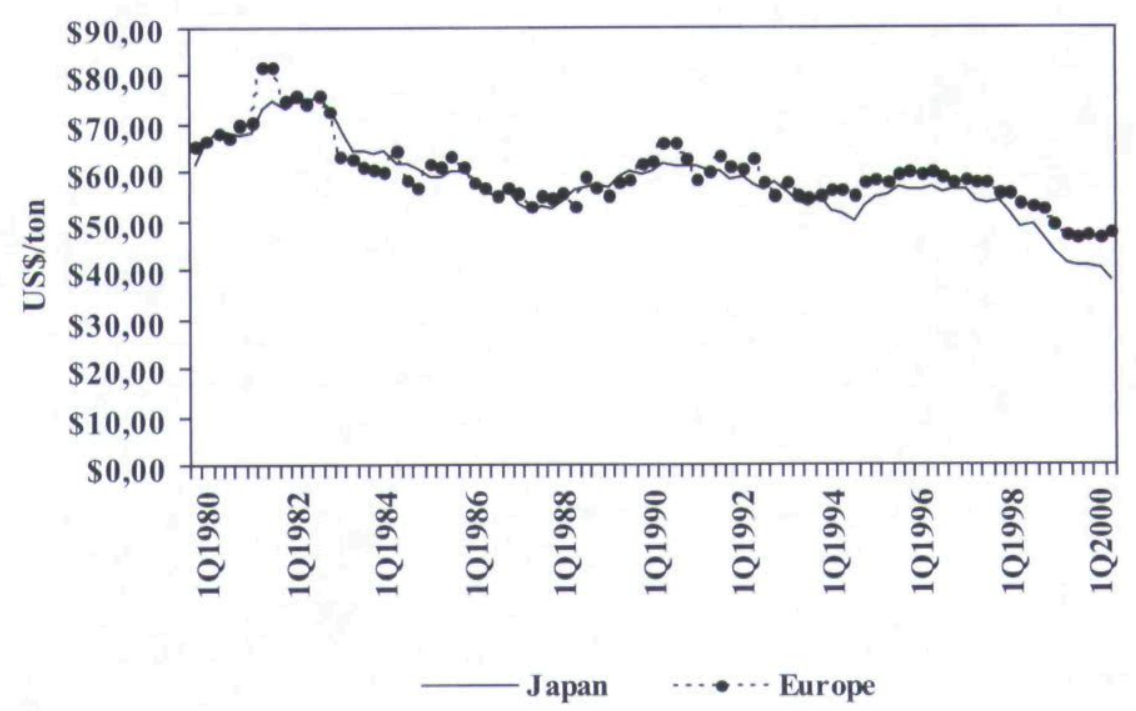

Source: IEA (quarterly). 
Despite the existence of long-term contracts, the prices for coking coal are considered to be relatively flexible. Annual renegotiations, allowing the prices to change, are the norm. The timing of the negotiations has a great impact on the prices, and for the coking coal market, the price settlements with the Japanese steel mills are the most influential. These settlements are made before the negotiations involving European and South African steel makers. In Japan it has also been common to conclude negotiations for coking coal before steam coal, mainly because the Japanese steel mills have a longer tradition of coal importation than the Japanese power utilities have (IEA, 1997).

\subsection{Steam Coal}

Steam coal is primarily used for electricity generation, and in recent years it has represented more than 60 percent of all traded coal. Compared to the coking coal market, the steam coal market has grown considerably faster during the last 20 years, mainly because of the substantial increase in electricity demand during this period (IEA, 2000). The oil crises in 1973 and 1979 were the two individual events that have had the most impact on the creation of a world market for seaborne steam-coal trade. The high oil prices enforced by the OPEC cartel substantially increased the demand for internationally traded steam coal. Transportation costs and storage costs for steam coal seemed no longer to be an overwhelming obstacle, especially since 'security of supply' became a political issue that appeared as important as a cost-driven perspective (Söderholm, 1998).

In 2000 , the total volume of trade in steam coal was 381 million tons, and Australia and South Africa were the largest exporters with shares of 23 percent and 18 percent, respectively. Figure 3 presents the quarterly steam coal prices for Europe and Japan from 1980 until 2000.

The price series seem to be highly correlated once again, and we can also see that the price levels for steam coal are slightly lower than the price levels for coking coal. The primary reason is that coking coal is of higher quality content. The contractual arrangements for steam coal are mostly the same as those for coking coal. So far long-term contracts are dominating the market, but spot markets are becoming increasingly common in the price-formation process. The spot purchasing practice is more developed for steam coal than that for coking coal, primarily because of the greater number of supply alternatives in the steam coal market. The steam coal prices in the Asian market are influenced by the prices set in the European market, since prices in the European market are mostly set one quarter ahead of the prices in Asia (IEA, 1997).

Figures 2 and 3 illustrate that the prices for coking coal and steam coal have roughly followed the same path. Imports prices around the world, for steam coal and coking coal, were at their 'all time high' in 1982, and have thereafter declined, both in nominal and in real terms. This is mainly due to increases in productivity, a more open and unregulated market and the oil price collapse in 1986. The high coal prices in the early 1980s created an excess supply capacity 
Figure 3. Import Prices for Steam Coal

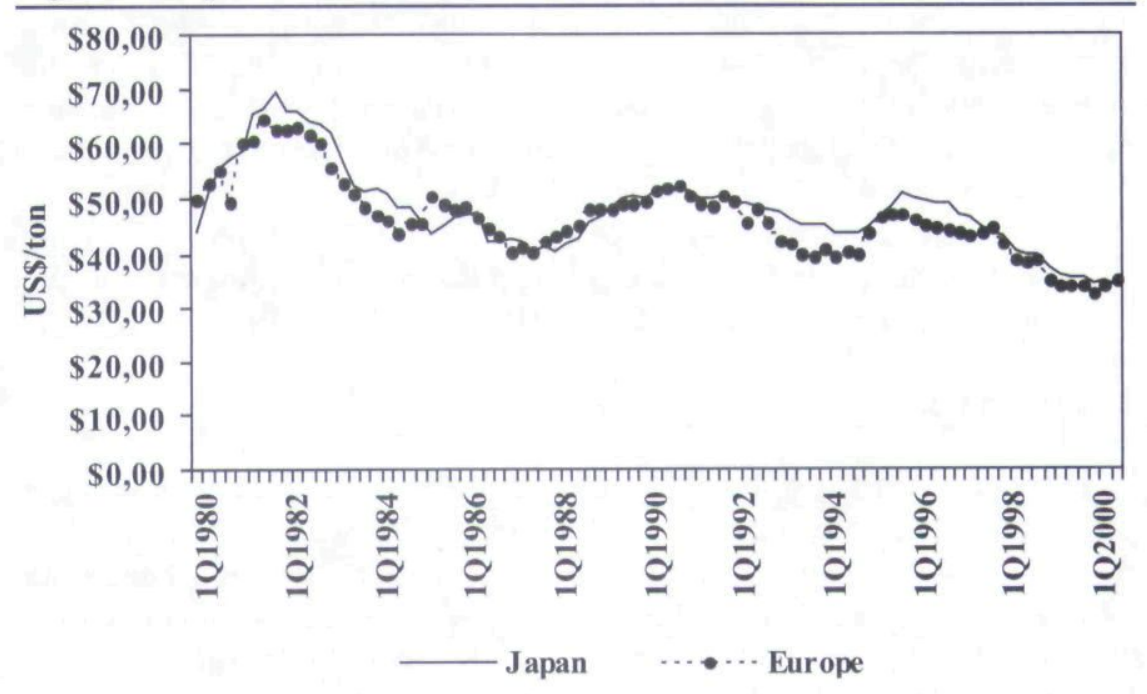

Source: IEA (quarterly).

for coal, which coincided with cheaper nuclear power plants, higher ocean freight rates, and environmental concerns for coal use. As a result, the demand growth for coal declined and the coal price was thereafter mostly determined by coalto-coal competition. Other factors that have contributed to a downward pressure on world coal prices are the widely distributed coal reserves, the possibility for US producers to enter the market when prices rise, and the entry of new low cost producers from new exporting countries (IEA, 1997).

\subsection{Is there a Single Economic Market for Internationally Traded Coal?}

One aspect of the international coal market which contradicts the notion of a unified global economic market is the domination of two geographical markets. These are the European and the Asian-Pacific markets. The existence of two geographically separated markets is sustained primarily by relatively high transportation costs and the bulky nature of coal products. Table 1 presents world trade in coking and steam coal in 2000. It is evident that countries that are geographically closer or neighbouring have higher mutual trade. The Asian-Pacific market, with Japan as the biggest importer, is mainly supplied by Australia and Canada in the case of coking coal and for steam coal by Australia, China, and Indonesia. The other regional market, Europe, is mainly supplied by South Africa, Colombia, and Poland for steam coal, and for coking coal by the US and Australia.

For steam coal, two important links between these geographically separated markets are Australia and in particular South Africa, whose geographic 
locations create potential for exports to both the European and Asian-Pacific markets. In the case of coking coal we can see that Australia exports both to the Asian-Pacific market and to the European market. This is primarily explained by the excess supply from the Australian producers. Australia can therefore be seen as a marginal supplier. Another link between the markets is the possibility for the US producers to enter the international coal market when price levels are favourable. This makes the US a swing-supplier with the excess capacity to move in and out of the market depending on the current market situation (IEA, 1997). ${ }^{3}$ The above facts, and the relatively strong relationship between coal prices, as illustrated in Figures 2 and 3, tend to support the notion of a unified market for internationally traded coal (see also Ellerman, 1995).

\section{Table 1. World Trade in Coking and Steam Coal in 2000 (Mt)}

\begin{tabular}{|c|c|c|c|c|c|c|}
\hline Exporters & Japan & $\begin{array}{c}\text { king Co } \\
\text { Other } \\
\text { Asia }\end{array}$ & $\begin{array}{l}\text { OECD } \\
\text { Europe }\end{array}$ & Japan & $\begin{array}{c}\text { Steam Coal } \\
\text { Other } \\
\text { Asia }\end{array}$ & $\begin{array}{l}\text { OECD } \\
\text { Europe }\end{array}$ \\
\hline Australia & 40.7 & 28.4 & 21.6 & 46.8 & 28.7 & 9.9 \\
\hline Canada & 12.1 & 5.4 & 6.7 & 1.3 & 1.7 & 0.3 \\
\hline Poland & - & - & 4.0 & - & - & 18.1 \\
\hline United States & 1.0 & 0.9 & 15.7 & 3.1 & 1.1 & 5.8 \\
\hline Other OECD & 0.9 & 0.5 & 4.3 & - & - & 6.7 \\
\hline Total OECD & 54.8 & 35.3 & 52.3 & 51.1 & 31.5 & 40.9 \\
\hline China & 3.3 & 3.2 & - & 13.2 & 35.6 & 2.9 \\
\hline Colombia & 0.1 & - & 0.1 & - & - & 21.8 \\
\hline Indonesia & 3.9 & 4.3 & 0.4 & 10.5 & 30.0 & 8.0 \\
\hline Former SU & 2.4 & 1.0 & 1.2 & 3.1 & 2.3 & 17.2 \\
\hline South Africa & 0.3 & - & 0.4 & 1.6 & 11.5 & 41.8 \\
\hline Oth Non-OECD & - & - & 0.3 & 1.0 & 0.7 & 3.7 \\
\hline Tot. Imp/Exp & 64.7 & 43.8 & 54.8 & 80.6 & 110.9 & 136.3 \\
\hline
\end{tabular}

Source: IEA (2001).

Still, even if the prices tend to follow the same path in the long-run, the responses to price deviations in the short-run provide useful information. In addition, the recent development of more concentrated coal suppliers may be an issue of concern, since the prospect of these companies exercising market power increases substantially when there are fewer more dominant players operating in the market (IEA, 2000). An additional reason for the chosen topic is that previous research has to a large extent focused on the steam coal market. However, the assumption about a single economic market is often made for the international coal market as a whole (e.g., IEA, 1997).

3. Market integration between the US and Europe because the US role as swing supplier is considered to be strong (Ellerman, 1995). It is therefore reasonable to believe that any regional tendencies (i.e., lack of market integration) are more likely to be detected between Europe and Japan. Also worth noting is that the US is not a big importer of coal, given its large domestic production. 


\section{COINTEGRATION AND ERROR-CORRECTION MODELS}

The method for determining market integration in this article is the errorcorrection model introduced by Engle and Granger (1987). The error-correction model incorporates a long-run cointegrating relationship, which implies that two cointegrated price series will not drift apart without limit. Error-correction models have gained increased support for empirical estimations of market integration in energy industries during the last ten years (e.g., deVany and Walls, 1993; Sauer, 1994; Asche et al., 2001). The technique examines movements in prices for goods located in different regions in order to test the hypothesis of a long-run cointegrating relationship. The examination of market integration in the international coal market follows two steps. First, the cointegration relationship is investigated in order to determine whether the two price series show evidence of stable long-run relationships. The finding of cointegration is however not sufficient to verify that two regions belong to the same market (Gjolberg, et al., 1996). An investigation of the price adjustment process, where significant responses to different price shocks can be recognized, provides further evidence for market integration. The adjustment is considered a short-run process and represents the second step in the examination of market integration. The analysis of the speed and strength of the adjustment back towards the long-run equilibrium level will help to determine market integration.

Consider two price series, $p_{i}$ and $p_{j}$, that by themselves are non-stationary, $I(1)$, and must be differenced once to generate stationarity. A linear transformation of the two original series can though result in a series $\varepsilon_{t}$ that is stationary, $I(0):^{4}$

$$
p_{j, t}-\alpha-\beta p_{i, t}=\varepsilon_{t}
$$

If this linear transformation exists between $p_{i}$ and $p_{j}$, the time series are considered cointegrated since the regression indicates that the difference between the time series, $p_{j, t}-\beta p_{i, t}$, is varying at random around a fixed level (Engle and Granger, 1987). When this is the case, it is possible to distinguish between a long-run and a short-run relationship between $p_{i}$ and $p_{j}$. The long-run relationship captures the cointegration relationship, in which the series move together around a fixed level. The short-run relationship describes deviations of $p_{i}$ and $p_{j}$ from their long-run trends. The vector $[1,-\beta]$ in equation (1) captures the cointegration relationship between the two price series. When cointegration between time series is evident there is an indication of a single market.

The model that differentiates between a long-run and a short-run relationship for time series analysis has been widely known as the error-correction mechanism (ECM) model (Engle and Granger, 1987). The so called generalized error-correction equation is presented in equation (2). If $p_{i}$ and $p_{j}$ are cointegrated

4. This is only true if $p_{1}$ and $p j$ are integrated of the same order, in this case integrated of order one (Greene, 1993). 
there are additional parameter restrictions. Engle and Granger (1987) achieved this by introducing equation (3) in which they separately estimated the coefficients for $\alpha$ and $\beta$.

$$
\Delta p_{j, t}=\beta \Delta p_{j, t-k}+\beta \Delta p_{i, t-k}+\delta E C_{t-1}+\varepsilon_{t},
$$

where $k$ represents the lag-length and the error-correction term is represented by $E C_{t-1}$, which adopts the following form:

$$
E C_{t-1}=p_{j, t}-\alpha-\beta p_{i, t-1}
$$

this term thus captures the deviation from long-run equilibrium, and the coefficient $\delta$ in equation (2) measures the speed of adjustment, which indicates how long it takes for the time series to move back to the equilibrium level in case of a price shock in one region. The coefficients $\beta_{i}$ and $\beta_{j}$ represent the short-run counterparts to the long-run solution in equation (2).

Werden and Froeb (1993) criticize the use of price series data to define the relevant market. There are primarily two reasons for this conclusion. First, it is often difficult to identify the correct price and transportation cost, when the geographically separated markets include a variety of products with different prices, and conclusions based on poor data may be misleading. Second, even if prices for products sold in geographically separated markets follow the same trend, it does not necessarily mean that they belong to the same economic market. For example, the change in a common input factor would cause the prices in separate markets to move together, even if the products belong to separate markets. This is often called spurious correlation. Given this situation, an assessment of the two price series would induce the wrong assumption of an integrated geographic market area, when in fact this is not the case.

\section{RESULTS FOR THE INTERNATIONAL COAL INDUSTRY 1980-2000}

The European and Japanese data used represent quarterly import prices for coking and steam coal from the first quarter in 1980 to the third quarter in 2000. These have been collected from the International Energy Agency's (IEA's) quarterly publication Energy Prices and Taxes, and represent import CIF prices in US Dollars/ton, including the sum of cost, insurances and freight. ${ }^{5}$ The econometric model outlined in section 3 will be employed with variables in logarithms. ${ }^{6}$

Chang (1995) discusses the difference in using FOB (free on board) prices and CIF (cost, insurance, and freight) prices in evaluating price differences for coal. CIF prices are often derived by adding an estimated transport cost to the

5. The prices used are so-called blended prices (BTU).

6. The logarithmic form avoids having growth rates depend on the levels of the price series (Hendry and Juselius, 2001). The coefficients also become easier to interpret, since they are scale invariant. 
FOB contract prices, and thus the quality of the CIF price thus depends on the accuracy of the estimated transport costs. However, for the analysis conducted in this paper it is important to include the transport costs. Since specified prices of origin with respective transportation costs data are not available, CIF prices are considered to be the best proxy available for a spatial analysis.

Another caveat is that CIF prices are blended prices, where for example multi-year contract prices are blended with spot prices. CIF prices blend delivered prices for coal shipped from scattered sources to a common destination. It also blends for coal with slightly different qualities. Thus, the coal prices used here are averages and do not always reflect the actual price paid. However, given the range of different prices this would generate, some averaging is necessary. A potential complication with using blended or averaged prices is that systematic variations in the unobserved characteristics may be present. This would be the case if there was evidence that changes in the length of contracts were different in Japan than in Europe, or if there were transport cost changes during the period that affected Japanese or European buyers differently. However, there is no evidence that any systematic variations in the unobserved characteristics are so substantial that the results of this paper should be overthrown for this reason.

The results for the two separate markets, coking and steam coal, are presented after testing the price series for a unit root, a necessary condition for cointegration. The Augmented Dickey-Fuller (ADF) tests, using up to four lags, show the presence of a unit root in coking and steam coal price series, for both Europe and Japan. ${ }^{7}$ When using quarterly data it is reasonable to consider seasonal unit roots, i.e., $\Delta_{4} p_{t}=p_{t}-p_{t-4}$. Tests for whether to use seasonal unit roots, instead of non-seasonal unit roots, have been performed according to the HEGY procedure (Hylleberg, et al., 1990). Both for coking and steam coal price series it is not possible to reject the null hypothesis of non-seasonal unit roots.

The Engle and Granger test uses a standard OLS estimation for the long-run relationship between the two price series. In order to conclude that the price series are cointegrated, the residuals from the OLS estimation have to obey stationarity. When this is the case, the residuals from the cointegrating relationship are incorporated in the ECM model and the equation then only consists of stationary variables, so standard estimation procedures can be applied (Dolado et al., 1990).

\subsection{Cointegration Results for Coking Coal}

The regression of prices in Japan $\left(P_{J}\right)$ on prices in Europe $\left(P_{E}\right)$ and a constant was run. The result, normalized on Europe, has the following representation:

$$
\begin{aligned}
P_{E}= & 1.04+0.75 P_{J} \\
& (-7.66)(-22.5)
\end{aligned}
$$

7. The results from the ADF tests are summarized in the Appendix. 
Equation (4) indicates that when the price in Japan rises by one percent, the corresponding long-run increase in the European price level is 0.75 percent. The values in the parentheses represent the t-statistics. An economic interpretation of the intercept is that it represents the price differences between the time series in the long-run, which in the case of coal incorporates transportation costs and quality differences. The sign indicates that the price level in Japan is lower than the price level in Europe, as is also evident when looking at Figure 2. For cointegration, the residuals from Equation (4) have to obey stationarity. The DF test statistics is -4.52 , rejecting the null hypothesis of a unit root at the one-percent level and therefore implying that the price series in Japan and Europe are cointegrated.

Since choice of dependent variable when using prices is not clear, the same procedure was repeated for the reverse regression. The result, normalized on Japan, is presented in Equation (5):

$$
\begin{aligned}
P_{J}= & -0.63+1.15 P_{E} \\
& (-3.03)(-22.5)
\end{aligned}
$$

Equation (5) shows the opposite relationship, i.e., when the prices in Europe rise by one percent, the corresponding long-run increase in the Japanese price level is 1.15 percent. The result form this regression confirms the conclusion of a higher price level in Europe than in Japan. The DF test statistic of -3.9 again confirms that the price series in Europe and Japan are cointegrated, and thus the error-correcting dynamics can be tested for. ${ }^{8}$ However, given that coking coal prices in Japan are set before the prices in Europe (see section 2), it is reasonable to believe that the results when normalizing on European prices provide more information.

The error-correction model used is given in equation (2). Regressions with up to four lags have been performed, but presented in the tables are only models where the lag-length is one. These were the models that produced statistically significant coefficients. Note that the model already includes one lag given the regression of changes in prices. The dependent variable is European prices in equation (6), but an estimation using Japanese prices as the dependent variable has also been performed. We have thus:

$$
\Delta p_{E, t}=b_{E} \Delta p_{E, t-1}+b_{J} \Delta p_{J, t-1}+\delta E C_{t-1},
$$

where $b_{J}$ and $b_{E}$ are the estimated short-run counterparts to the long-run solution, and $d$ represents the speed of adjustment parameter, which indicates how fast the prices move back towards long-run equilibrium in case of a deviation in the previous time period. Table 2 presents the estimated values of these parameters, using both prices in Europe and Japan as the dependent variables.

8. The conclusion of cointegration between coking coal prices in Europe and Japan is also confirmed when performing a Johansen ML test. The results from this test are summarized in the Appendix. 
Table 2. Error-Correction Estimates (Coking Coal)

\begin{tabular}{lcccccc}
\hline & \multicolumn{3}{c}{ EUROPE } & \multicolumn{3}{c}{ JAPAN } \\
Coefficients & $\boldsymbol{b}_{E}$ & $\boldsymbol{b}_{\boldsymbol{J}}$ & $\delta_{E}$ & $\boldsymbol{b}_{\boldsymbol{J}}$ & $\boldsymbol{b}_{\boldsymbol{E}}$ & $\delta_{J}$ \\
\hline Estimate & 0.03 & $\mathbf{0 . 4 1 ^ { * }}$ & $\mathbf{- 0 . 3 8 ^ { * }}$ & $\mathbf{0 . 2 0}$ **** & 0.09 & -0.03 \\
t-values & $(0.28)$ & $(2.58)$ & $(-3.20)$ & $(1.69)$ & $(0.97)$ & $(-0.47)$ \\
\hline
\end{tabular}

*Bold numbers indicate statistical significance at * $1 \%$ level, ** $5 \%$ level, and *** $10 \%$ level.

The results using prices in Europe as the dependent variable indicate that a one-percent increase in prices in Japan in the preceding period yields a 0.41 percent increase of the price level in Europe in the present time period. This suggests that the prices in Europe are reacting to price changes in Japan in the previous time period. The speed of adjustment parameter implies that a deviation from the long-run equilibrium in Japan in the preceding time period creates an adjustment by 38 percent in Europe the following quarter. Turning the attention to the results when using Japanese prices as the dependent variable we can see that none of the short-term response parameters are statistically significant.

In summary, it is evident that coking coal prices in Europe and Japan are cointegrated and therefore follow a long-run relationship. This result supports the hypothesis of an integrated world market for coking coal. When examining the short-run response to the long-run equilibrium we can see that a change in the Japanese prices in the previous period will be adjusted for by almost 40 percent in Europe the following period. However, there is no evidence of Japanese prices adjusting to price changes in Europe. This result may be explained by the timing of price negotiations, since coking coal prices in Japan normally are settled before the prices in Europe (see section 2).

\subsection{Cointegration Results for Steam Coal}

The tests for cointegration and error-correction for the steam coal market follow the same general procedure as for coking coal. The long-run equilibrium results, normalized on Europe and Japan, are as follows:

$$
\begin{aligned}
& P_{E}=0.30+0.91 P_{J} \quad P_{J}=0.21+0.95 P_{E} \\
& \text { (2.00)(23.39) (1.35) (23.39) }
\end{aligned}
$$

Equation (7) indicates that when the price in Japan (Europe) increases by one percent, the corresponding long-run increase in the European (Japanese) price level is 91 (95) percent. Compared to the coking coal market, it is evident that the price changes are closer to one. For cointegration the residuals from Equation (7) have to obey stationarity. The DF test statistics are -4.82 and -4.65 respectively, which is statistically significant. This implies that the price series in Japan and Europe are cointegrated. ${ }^{9}$ Given the price formation, i.e., that prices in Europe are 
set before prices in Japan, the equation normalizing on Japanese prices is likely to entail more information.

The error-correction model is once again performed as outlined in equation (6). Table 3 presents the estimated values of these parameters, using both Europe and Japan as the dependent variable. The results when using Europe as the dependent variable show that none of the short-run response parameters are statistically significant at an acceptable level. When using Japan as the dependent variable, a one-percent increase of the price in Europe in the preceding period yields a 0.25 percent increase of the price level in Japan in the present time period. The result of a price change in the own region the preceding time period is thus adjusted for by 25 percent in the following time period. The speed of adjustment parameter is 0.17 when using Japan as the dependent variable. Compared to the results for the coking coal market, these findings indicate that it is the European prices that seem to influence the Japanese and not vice versa.

Table 3. Error-Correction Estimates (Steam Coal)

\begin{tabular}{lcccccc}
\hline Coefficients & $\boldsymbol{b}_{E}$ & $\begin{array}{c}\text { EUROPE } \\
\boldsymbol{b}_{\boldsymbol{J}}\end{array}$ & $\delta_{E}$ & $\boldsymbol{b}_{J}$ & $\begin{array}{c}\text { JAPAN } \\
\boldsymbol{b}_{\boldsymbol{E}}\end{array}$ & $\delta_{\boldsymbol{J}}$ \\
\hline Estimate & 0.003 & $\mathbf{0 . 2 5 * * *}$ & -0.16 & $\mathbf{0 . 2 5 *}$ & $\mathbf{0 . 2 1 *}$ & $\mathbf{- 0 . 1 7 ^ { * }}$ \\
t-values & $(0.20)$ & $(1.78)$ & $(-1.38)$ & $(2.76)$ & $(2.33)$ & $(-2.41)$ \\
\hline
\end{tabular}

* Bold numbers indicate statistical significance at * $1 \%$ level, ** $5 \%$ level, and *** $10 \%$ level.

In summary, the results for steam coal show that the European and the Japanese markets are integrated into one market, given the presence of cointegration. When examining the short-run responses, given by the adjustment towards the long-run equilibrium, the results show that European prices influence Japanese prices. This may once again be explained by the timing of price negotiations, since steam coal prices in Europe normally are settled before the prices in Japan (see section 2). It is notable that the short-run responses to price changes are lower for steam coal than for coking coal. This might be explained by the fact that coking coal prices are higher, and transportation costs constitute a larger part of the steam coal prices than the coking coal prices.

\subsection{Market Integration over Time}

In order to investigate whether the coal markets have experienced increased market integration over time, the price series have been separated into two time periods. The first period represents price data from quarter one in 1980 to quarter four in 1989, and the second time period represents prices from quarter one in 1990

9. See Appendix for Johansen test results for cointegration. The conclusion of cointegration is confirmed also for steam coal. 
until quarter three in 2000. The selection of 1990 as the breakpoint, besides it being the midpoint in the series, is motivated also by two empirical observations.

First, large structural changes occurred in Europe after 1990. Before the 1990s, the European coal market was highly subsidized, mainly due to security of supply concerns and the fact that European coal producers could not compete with low cost producers in other parts of the world. During the 1990s, a policy change towards a more cost efficient market approach that involves decreasing subsidies for coal was implemented both in Eastern and Western Europe. In Eastern Europe, where the Socialist economic regimes were replaced by more market-oriented regimes, the change was a natural cause in adapting to the WestEuropean standards (e.g., Radetzki, 1995). In Western Europe there has been a strong tendency towards privatization of state-managed economic activities and liberalization of trade. This initiated rationalization programs to coal production in many Western European countries (Radetzki, 1994).

Second, the changes in the contractual arrangements for the coal industry were mainly introduced during the 1990s. In 1991 the MCIS (McCloskey Coal Information Services), providing a marker-price to spot prices in North-West Europe, was first published. In 1992 the TaiPower, the Asian equivalent of MCIS, was introduced. Since then there has been a movement away from five-year contracts towards contracts that are characterized by a shorter perspective, such as spot prices and contracts that are renegotiated annually. It is worth noting that this development has been most significant regarding steam coal, mainly due to the increased demand for steam coal and because industries using coking coal is more dependent upon a specific coal quality (IEA, 2000).

The general procedure of the error-correction analysis, separated into two time periods, is the same as outlined above. The first step is to test for unit roots. The results from the ADF tests indicate that the price series are non-stationary in level, and become stationary after first differencing. Before estimating the longrun and short-run relationships it is however of interest to determine whether it is at all reasonable to divide the price series into two time periods, with different model parameters. The test on parameter restrictions is a classical F-test, often referred to as a Chow test. This test verifies whether the improvement in the fit due to splitting the sample is statistically significant or not (Dougherty, 1992). The test statistic is 6.03 for steam coal and -1.87 for coking coal. Given a critical value of 3.15 , these results imply that separating the price series into two time periods is justified for steam coal but not for coking coal.

The results from the long-run cointegration relationships for steam coal, separated in the two time periods, are presented in Table 4 . They indicate that the long-run price change in one region, due to a one-percent increase in the other region, is stronger in the 1990 s compared to the $1980 \mathrm{~s}$. This is especially evident when regressing prices in Japan on prices in Europe. A one-percent increase in the price level in Japan yields a 0.99 percent increase in the European price level in the $1990 \mathrm{~s}$, compared to 0.76 percent in the $1980 \mathrm{~s}$. To achieve cointegration, the residuals from the regressions presented in Table 4 have to obey stationarity. 
When regressing the change in the residuals on past levels and no lagged changes, the results show that in the 1980 s the residuals obey stationarity. This implies that the price series in Japan and Europe are cointegrated in the 1980s and thus that error-correction estimates can be employed. However, when turning the attention to the 1990s we cannot find evidence of cointegration based on the DF test. Given that the price series are not cointegrated, the error-correction model will impose parameter restrictions that are invalid. The error-correction estimates will therefore only be presented for the 1980s.

Table 4. The Long-run Cointegration Results for Selected Time Periods

\begin{tabular}{lcccc}
\hline STEAM COAL & \multicolumn{2}{c}{ 1980Q1-1989Q4 } & \multicolumn{2}{c}{ 1990Q1-2000Q3 } \\
\hline & Japan & Intercept & Japan & Intercept \\
\hline Estimate & 0.76 & 0.93 & 0.99 & -0.01 \\
t-values & $(15.01)$ & $(4.66)$ & $(18.58)$ & $(-0.07)$ \\
\hline & Europe & Intercept & Europe & Intercept \\
\hline Estimate & 1.13 & -0.48 & 0.90 & 0.42 \\
t-values & $(15.01)$ & $(-1.62)$ & $(18.58)$ & $(2.28)$ \\
\hline
\end{tabular}

The error-correction model for the 1980s is estimated as outlined in equation (6). Table 5 presents the estimated values of these parameters, using both European prices and Japanese prices as the dependent variables. The results, when normalizing on Europe, show that none of the short-run response parameters are statistically significant at an acceptable significance level. When using Japan as the dependent variable the results show that the effect of a one-percent increase of the price level in the own region in the preceding period will lead to an increase in the price level by 0.27 percent in the present quarter. The speed of adjustment parameter indicates that the prices move back to the equilibrium level by 29 percent after the first quarter.

Table 5. Error-Correction Estimates for Selected Time Periods

\begin{tabular}{lcccccc}
\hline STEAM COAL & \multicolumn{3}{c}{ EUROPE } & \multicolumn{3}{c}{ JAPAN } \\
1980Q1-1989Q4 & $\boldsymbol{b}_{E}$ & $\boldsymbol{b}_{\boldsymbol{J}}$ & $\delta_{E}$ & $\boldsymbol{b}_{J}$ & $\boldsymbol{b}_{E}$ & $\delta_{J}$ \\
\hline Estimate & 0.03 & 0.22 & -0.31 & $\mathbf{0 . 2 7 * *}$ & 0.16 & $\mathbf{- 0 . 2 9 * *}$ \\
t-values & $(0.16)$ & $(1.25)$ & $(-1.38)$ & $(2.25)$ & $(1.10)$ & $(-2.29)$ \\
\hline
\end{tabular}

* Bold numbers indicate statistical significance at * $1 \%$ level, ** $5 \%$ level, and *** $10 \%$ level.

The results from the long-run relationship between prices in Europe and Japan indicate that the long-run price adjustment to changes in the other region is larger in the 1990s than in the 1980s. However, when analyzing the cointegration relationship the results show that steam coal prices for the 1990s are not cointegrated. One likely explanation to this rather surprising result is that the 


\section{4 / The Energy Journal}

prices used in the regression are based on customs unit values. Customs unit values are average values derived from customs' administrations total volume and total value data. These data indicate broad price movements given that they reflect the contract terms and conditions under which the trade occurs. It would be preferred to use spot and tender prices reported in the trade press, given that these pertain to one time transactions and thus reflect more short-term market conditions. This provides a more accurate estimation of the price formation process.

\section{Figure 4. Spot and Tender CIF Prices for Steam Coal}

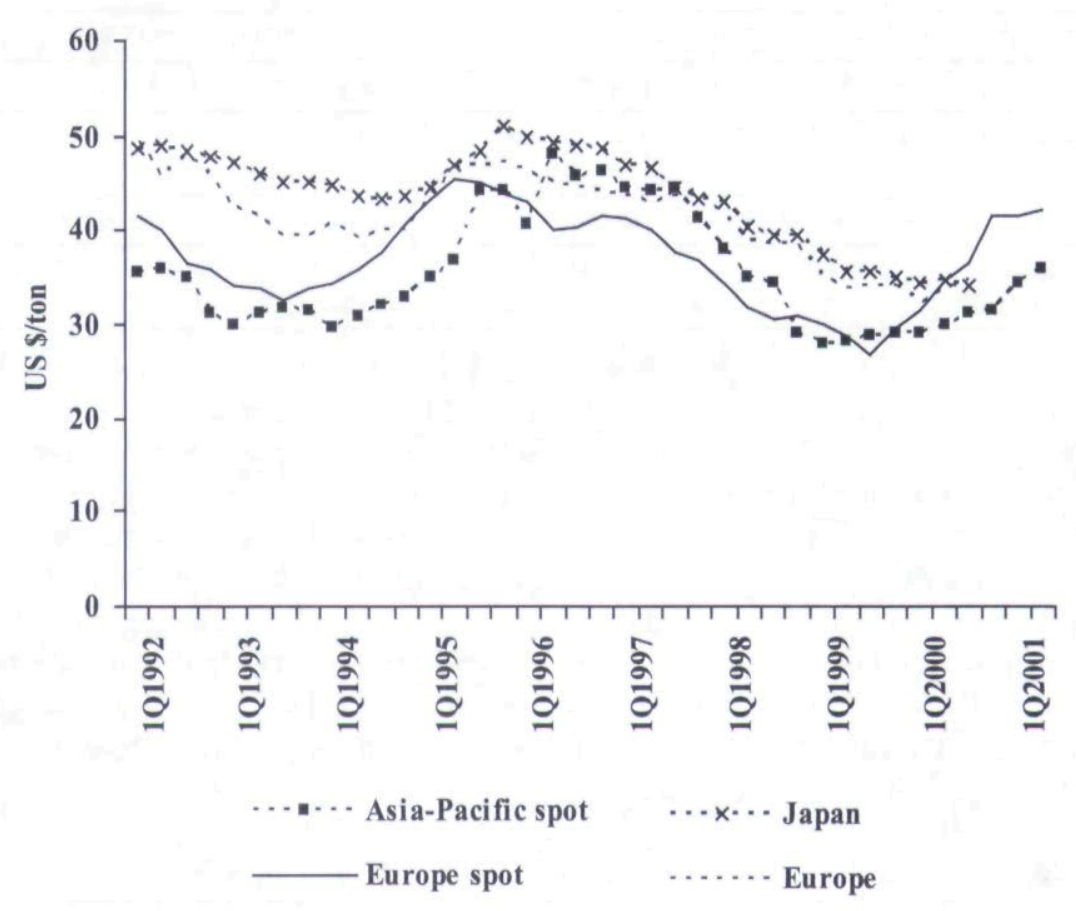

Source: IEA (2001).

A regression using spot and tender prices for steam coal during the 1990s has therefore been conducted. Spot and tender prices before this time period are not available, which is why the previous regressions have not used spot prices. Figure 4 shows quarterly averages of spot and tender prices collected by Taipower in the Asia Pacific market, and by MCIS in the European market. Also presented are the reported customs unit values of steam coal during the same time period. The Figure indicates that the spot prices are generally lower than the customs unit values. As well, there seems to be rather large variations between the spot prices in Europe and Japan. 
The DF tests do not reject unit roots in levels, but do when variables are first differenced. This implies that tests for cointegration can be applied. The results when regressing spot prices in Asia-Pacific on spot prices in Europe, and vice versa, are presented in Table 6 . The results indicate that that the long-run price change in one region, due to a one-percent increase in the other region, is not as large as when regressing customs unit values. When the price in Asia-Pacific increases by one percent, the corresponding long-run increase in the European price level is 0.57 percent, compared to 0.99 percent in Table 4 . The results when regressing prices in Europe on prices in Asia-Pacific show a similar result.

Table 6. The Long-run Cointegration Results Using Spot Prices

\begin{tabular}{lcccc}
\hline STEAM COAL & \multicolumn{4}{c}{ 1992Q1-2001Q2 } \\
\hline & Japan & Intercept & Japan & Intercept \\
\hline Estimate & 0.57 & 1.56 & 0.61 & 0.82 \\
t-values & $(5.64)$ & $(4.30)$ & $(5.64)$ & $(1.18)$ \\
\hline
\end{tabular}

For cointegration the residuals from the regressions presented in Table 6 have to obey stationarity. However, when regressing the change in the residuals on past levels, with or without lagged changes, the results show that the residuals do not obey stationarity. This result is in line with the finding from regressing average steam coal prices in the 1990s. Thus, the spot markets in Europe and Asia-Pacific cannot, according to the cointegration results, be considered as integrated in the 1990s. To conclude, the results indicate that the long-run price change in one region, due to a one-percent increase in the other region, is stronger in the 1990s. However, the price series are not cointegrated, either when using custom unit values or spot and tender prices. One should though be cautious when analyzing the results of market integration over time, given that the data set is reduced by half. A data set with fewer observations will be more sensitive than a data set with more observations.

\section{CONCLUDING REMARKS AND POLICY IMPLICATIONS}

The purpose of this paper has been to test the hypothesis of the existence of a single economic market for the international coal industry and to investigate whether the industry has experienced increased market integration over time. This has been conducted by analyzing whether the steam and coking coal price series in Europe and Japan are cointegrated. The results, when examining the entire time period, show that both the coking and steam coal markets indicate the existence of a world market, as demonstrated by the long-run cointegrating relationship between the price series in the different world regions. A policy implication from this result would be that mergers within a particular country or region ought to be less problematic, since the relevant boundary for the steam and coking coal markets are world-wide instead of regional. 
To strengthen this result, the short-run adjustments to the long-run levels have also been studied. These results seem to indicate a faster adjustment towards the long-run equilibrium for coking coal than for steam coal. Thus, there are tendencies towards greater integration for coking coal. Noteworthy is that the short-run price adjustments are only significant from one direction, both for coking coal and steam coal. In the coking coal market, the results are consistent with Japanese prices influencing European prices, and vice versa in the steam coal market. This result may be explained by the timing of price negotiations, where the Japanese prices are normally settled before the European prices concerning coking coal, and vice versa for steam coal.

In order to test for market integration over time, the price series data have been separated into two time periods, the 1980s and the 1990s. The structural break in 1990 is confirmed for steam coal, but not for coking coal. The results regarding steam coal show that cointegration cannot be confirmed in the 1990s, and therefore it cannot be concluded that a world market existed in the 1990s. Furthermore, when conducting the same regression using spot prices, this rather surprising result is confirmed. A policy implication of the finding that the steam coal market cannot be considered cointegrated in the $1990 \mathrm{~s}$, is that the market has become more regional in scope. It is thus likely that a merger during this period might have added more to the merged companies' market power, as it would have during the $1980 \mathrm{~s}$.

However, the finding of non-cointegration for the steam coal market in the 1990s does not have to imply that competition on the market is constrained. Defining market boundaries is only a first step in competition analysis. Thus, the method applied is limited when analyzing antitrust issues, but it still provides useful information and guidance for the antitrust practitioner. An important caveat concerning the errorcorrection model is that it is sensitive to the different econometric specifications, i.e. how many lags to include, should an intercept and trend be included in the model and so on. All results should therefore be treated cautiously, and reliant upon the specified levels and orders. We therefore conclude that the results produced in this paper need to be reinforced by the use of other methods in order to provide a more comprehensive analysis of market integration in the international coal market.

\section{REFERENCES}

Asche, F., L. Osmundsen, and R. Tveterås (2001). "Market Integration for Natural Gas in Europe." International Journal of Global Energy Issues 16(4).

Chang, H. (1995). "Examining Hard Coking Coal Price Differentials: A Hedonic Price Approach." Resources Policy 21(4): 275-282.

deVany, A.S., and W.D. Walls (1993). "Pipeline Access and Market Integration in the Natural Gas Industry: Evidence from Cointegration Tests." The Energy Journal 14(4): 1-19.

Dolado, J., T. Jenkinson, and S. Sosvilla-Rivero, (1990). “Cointegration and Unit Roots.” Journal of Economic Surveys 4(3): 246-273.

Dougherty, C. (1992). Introduction to Econometrics. New York, Oxford University Press.

Ellerman, A.D. (1995). "The World Price of Coal." Energy Policy 23(6): 499-506.

Engle, R.F., and C.W.J. Granger (1987). "Co-integration and Error Correction: Representation, Estimation and Testing." Econometrica 55: 251-276. 
Gjolberg, O., A. Guttormsen, and L. Aarstad (1996). "When will European Agriculture Join the Common Market? Wheat Market Segregation 1984-94.” Discussion Paper 9601, Department of Economics and Social Sciences, Agricultural University of Norway.

Greene, W. (1993). Econometric Analysis. New York, MacMillan.

Hendry, D., and K. Juselius (2001). “Explaining Cointegration Analysis: Part II.” The Energy Journal 22(1): 75-120.

Humphreys, D., and K. Welham (2000). "The Restructuring of the International Coal Industry." International Journal of Global Energy Issues 13(4): 333-347.

Hylleberg, S., R.F. Engle, C.W.J. Granger, and B.S. Yoo (1990). "Seasonal integration and cointegration." Journal of Econometrics 44(1-2): 215-238.

International Energy Agency (IEA) (quarterly). Energy Prices and Taxes. OECD, Paris.

International Energy Agency (IEA) (1997). International Coal Trade: The Evolution of a Global Market. Paris, OECD.

International Energy Agency (IEA) (1998). Coal Information 1997. Paris, OECD.

International Energy Agency (IEA) (2000). Coal Information 1999. Paris, OECD.

International Energy Agency (IEA) (2001). Coal Information 2000. Paris, OECD.

Keay, M. (2003). "The View from Europe - And Elsewhere." Oxford Energy Forum 52: February.

Lundgren, N-G. (1996). "Bulk Trade and Maritime Transportation Costs: The Evolution of Global Markets." Resources Policy 22(1-2): 5-32.

Radetzki, M. (1994). "Hard Coal in Europe: Perspectives on a Global Market Distortion." OPEC Review 18(2): 223-244.

Radetzki, M. (1995). Polish Coal and European Energy Market Integration. Aldershot, Avebury.

Regibeau, P. (2000). "The Global Energy Industry: Is Competition Among Suppliers Ensured?" International Journal of Global Energy Issues 13(4): 378-399.

Samuelson, P. (1952). "Spatial Price Equilibrium and Linear Programming." American Economic Review 42: 283-303.

Sauer, D.G. (1994). "Measuring Economic Markets for Imported Crude Oil." Energy Journal 15(2): 107-123.

Söderholm, P. (1998). "Fuel Choice in West European Power Generation Since the 1960s." OPEC Review 22(3): 201-232.

Werden, G., and L. Froeb (1993). "Correlation, Causality, and All that Jazz: The Inherent Shortcomings of Price Tests for Antitrust Market Delineation.” Review of Industrial Organization 8: 329-353.

\section{APPENDIX}

\section{Augmented Dickey Fuller (ADF) Test for Unit Root}

\begin{tabular}{|c|c|c|c|c|c|c|}
\hline \multicolumn{7}{|c|}{ COKING COALSTEAM COAL } \\
\hline Europe & Level & $\begin{array}{c}\text { First } \\
\text { Difference** }\end{array}$ & $\begin{array}{l}\text { Critical } \\
\text { Value* }\end{array}$ & Level & $\begin{array}{c}\text { First } \\
\text { Difference** }\end{array}$ & $\begin{array}{l}\text { Critical } \\
\text { Value* }\end{array}$ \\
\hline Constant & $-1.42(0)^{* * *}$ & $-8.93(0)$ & -2.90 & $-2.14(2)$ & $-7.25(0)$ & -2.90 \\
\hline Const + trend & $-2.26(0)$ & $-8.87(0)$ & -3.47 & $-2.91(2)$ & $-7.20(0)$ & -3.47 \\
\hline \multicolumn{7}{|l|}{ Japan } \\
\hline Constant & $1.00(0)$ & $-6.81(0)$ & -2.90 & $-2.40(4)$ & $-7.08(0)$ & -2.90 \\
\hline Const + trend & $-0.99(1)$ & $-6.94(0)$ & -3.47 & $-3.19(4)$ & $-7.01(0)$ & -3.47 \\
\hline
\end{tabular}

* The $95 \%$ critical values are reported.

** Bold numbers show that the null hypothesis (presence of unit root) $\mathrm{H} 0: \mathrm{g}=0$, is not rejected. *** The Akaike Information Criterion (AIC) and Schwarz Bayesian Criterion (SBC) have been used to select the number of lags, as is indicated in the parentheses. 
Selecting the Order of VAR for Johansen Test

\begin{tabular}{lcccc}
\hline & \multicolumn{2}{c}{ COKING COAL } & \multicolumn{2}{c}{ STEAM COAL } \\
\hline Order & AIC & SBC & AIC & SBC \\
\hline 6 & 299.90 & 269.43 & 301.94 & 271.47 \\
5 & 296.29 & 270.51 & 305.45 & 279.67 \\
4 & 299.34 & 278.27 & 306.30 & 285.21 \\
3 & 301.80 & 285.39 & 307.24 & 290.83 \\
2 & $\mathbf{3 0 3 . 7 9}$ & 292.07 & $\mathbf{3 0 8 . 2 9}$ & 296.57 \\
1 & 303.31 & $\mathbf{2 9 6 . 2 8}$ & 306.85 & $\mathbf{2 9 9 . 8 2}$ \\
0 & 170.86 & 168.51 & 153.23 & 150.88 \\
\hline
\end{tabular}

* The VAR models with one lag has been selected so that the risk of over-parameterisation is reduced.

Johansen Cointegration Long-run Test Based on Maximal Eigenvalue

\begin{tabular}{lcccc}
\hline & \multicolumn{2}{c}{ COKING COAL } & \multicolumn{2}{c}{ STEAM COAL } \\
\hline Null & Statistic* & 95\% Critical value & Statistic & 95\% Critical value \\
\hline $\mathrm{r}=0$ & $\mathbf{1 8 . 8 6}$ & 15.87 & $\mathbf{3 4 . 5 5}$ & 15.87 \\
$\mathrm{r}<=1$ & 4.83 & 9.16 & 1.21 & 9.16 \\
\hline
\end{tabular}

* Bold numbers indicate that the null hypothesis of no cointegration is rejected. Consequently, the null hypothesis of one cointegrating relation cannot be rejected. 
Copyright of Energy Journal is the property of International Association for Energy Economics. Inc. and its content may not be copied or emailed to multiple sites or posted to a listserv without the copyright holder's express written permission. However, users may print, download, or email articles for individual use. 